\title{
STRATEGI BERSAING : BATIK MALANGAN KONVENSIONAL MELALUI DIVERSIFIKASI PRODUK BATIK KOMBINASI PADA UKM KELURAHAN MERJOSARI MALANG
}

\author{
Adya Hermawati \\ Yatima El Isma \\ Nasharuddin Mas \\ Dosen Universitas Widyagama Malang
}

\begin{abstract}
ABSTRAKSI
Motif batik Malangan mengharapkan adanya suatu keluhuran dari pemakainya untuk selalu berdiri tegak, berani, bertanggung jawab dengan penuh rasa hormat agar mampu menyatu dengan lingkungan tempat tinggal. Potensi dan peluang usaha pengrajin batik malangan sangat prospektif. Setiap tahun banyak konsumen dari dalam maupun dari luar Kota Malang, terutama sekolah-sekolah dan perkatoran yang sudah menerapkan pemakaian batik, selalu mencari batik malangan sampai ke tempattempat produksi batik di Malang.

Pada UKM Pengrajin Batik Malangan di Kelurahan Merjosari Malang, teridentifikasi, perlu eksistensi dalam pengembangan usaha. Sementara pengembangan usaha batik saat ini perlu penerapan diversifikasi produk. Diversifikasi produk batik, faktanya menjadi peluang pasar. Strategi solusi yang harus diimplementasikan adalah basis diversifikasi produk batik kombinasi, dengan inovasi peralatan pencantingan batik kombinasi dan inovasi sarana pendukung yang diperlukan dalam proses produksi batik

Transformasi teknologi khususnya di bidang perbatikan sangat dibutuhkan oleh para UKM batik Malangan di Kelurahan Merjosari Malang. Sehingga cara meningkatkan produksi secara efisien, melalui diversifikasi produk dengan mentransformasi teknologi. Strategi tatakelola manajemen, menjadi pendukung utama dalam pengembangan usaha batik konvensional menjadi batik kombinasi. Tatakelola manajemen meliputi Planning, Organizing, Actuating, Controlling (POAC) menjadi fokus implementasi manajemen dalam rangka pengembangan produk batik kombinasi.
\end{abstract}

Kata Kunci: Batik Kombinasi, Diversifikasi Produk, Inovasi peralatan, Inovasi sarana pendukung, Program Manajemen, POAC

\section{LATAR BELAKANG}

Batik telah menjadi salah satu budaya yang secara turun temurun telah diwariskan oleh nenek moyang dan telah ditetapkan oleh UNESCO sebagai budaya asli Indonesia. Setiap kota di Indonesia memiliki batik sesuai dengan ciri khas masing-masing, begitu juga dengan daerah Malang. Batik khas Malang biasa disebut Batik Malangan karena semua inspirasi motifnya adalah semua yang ada di Malang. Batik Malangan memang belum sepopuler batik yang ada di daerah Jawa lainnya, namun keindahaan Batik Malangan tidak kalah bagusnya dengan batik yang ada di daerah lain. Batik Malangan memiliki corak batik yang khas dan unik. Peminat umumnya dari pengunjung luar daerah Malang dan juga wisatawan mancanegara.

Batik Malang berawal dari batik yang telah dipakai dalam upacara tradisional sejak abad XIX. Batik tersebut umumnya bermotif Sidomukti Malang dengan hiasan kotak putih di tengah yang biasa disebut Modhang Koro. Motif ini dipakai sebagai udheng (laki-laki) dan sewek (perempuan) dalam acara resmi untuk semua lapisan masyarakat. Batik Malangan memiliki tiga ciri pokok dan menjadi bagian dari tiga komponen pokok batik, yakni pertama pada tanahan atau dasar yang diambil dari motif batik di Candi Badut. Komponen kedua berupa motif pokok (hias isian) diisi dengan gambar Tugu Malang yang diapit oleh rambut singa pada sisi kiri dan kanannya sebagai lambang Kota Malang, serta komponen ketiga adalah motif hias untuk tumpal (pinggiran plus isenisen) yang diisi tiga sulur yang membentuk sebuah rantai. Motif hias berupa sulur-sulur bunga yang dimaksudkan untuk menggambarkan Malang sebagai kota bunga.

Eksistensi agar mampu berkompetisi, strategi solusi alternatif atas beberapa permasalahan yang dihadapi oleh UKM Batik konvensional Malangan menjadi sangat penting. Kondisi permasalahan, berdasar hasil survey yang dilakukan oleh Tim terhadap kondisi eksisting 2 Kelompok UKM Batik Konvensional di Kelurahan Merjosari Kota Malang 


\section{PERMASALAHAN}

Pada dasarnya permasalahan yang dihadapai UKM batik sangat beragam dan saling terkait antara permasalahan yang satu dengan lainnya. Namun demikian untuk mempermudah solusinya, maka permasalahan UKM batik konvensional di Kelurahan Merjosari Kota Malang dikelompokkan menjadi dua aspek utama yaitu permasalahan produksi dan permasalahan manajemen.

a) Permasalahan Produksi

Walaupun dari hasil analisis situasi pada UKM mempunyai kondisi yang sedikit berbeda, namun setelah ditelaah lebih seksama maka secara garis besar permasalahannya yang terjadi hampir sama. Permasalahan produksi teridiri dari:

1) Masalah proses produksi batik yang kurang bagus dan membutukan waktu lama. Hal ini disebabkan oleh keterbatasan inovasi peralatan utamanya pada peralatan pencantingan untuk membatik. Dengan keterbatasan peralatan maka kualitas maupun produktifitas hasil motif-motif batik Malangan masih rendah dan belum mampu bersaing.

2) Masalah pewarnaan batik masih sebatas menggunakan sarana manual. Sarana pewarnaan untuk mewarna hasil proses pencatingan dengan cara manual sehingga tidak bisa menghasilkan mutu pewarnaan yang bagus dan cepat. Hal ini disebabkan oleh faktor keterbatasan pengetahuan dan wacana SDM sehingga terjadi kualitas batik yang tidak maksimal.

b) Permasalahan Manajemen

Permasalahan manajemen untuk kedua mitra adalah:

1) Masih menggunakan sistem manajemen konvensional terutama pada pemasaran produk. Sebatas enawarkan dari sekolah ke sekolah dan perkantoran atau sistem door to door. Informasi produk hanya sebatas bisa diketahui dengan mendapat informasi dari mulut ke mulut, dari tetangga ke tetangga. Cara ini sangat tidak efektif sehingga membutuhkan waktu dan tenaga yang maksimal.

2) Masalah kendali mutu produk, belum adanya kendali kualitas produk yang bisa menjamin produk untuk siap bersaing. Batik malangan yang diserahkan ke konsumen kadang kala terkesan asal jadi motifnya, sehingga berdampak banyaknya komplain konsumen.

3) Belum dilakukan pembukuan yang tertib, arus kas masih tidak jelas, neraca bulanan belum diimplementasikan, masih belum dipetakan dalam pembukuan tersendiri antara keuangan usaha dengan keuangan untuk konsumsi keluarga. Hal inilah yang menyebabkan pengembangan usaha masih belum optimal.

\section{METODE PELAKSANAAN}

Untuk mencari solusi masalah yang dihadapi oleh mitra, metode pendekatan dilakukan sesuai dengan masing masing permasalahan, baik yang menyangkut produksi maupun manajemen.

\section{Strategi Solusi}

Untuk masalah produksi maka pendekatan yang ditawarkan untuk menyelesaikan persoalan tersebut adalah:

1) Pendekatan yang dilakukan untuk menyelesaikan masalah kurangnya inovasi peralatan batik, utamanya pada alat untuk proses pengcantingan batik. Sehingga teridentifikasi, hasil batik masih dalam kondisi kualitas belum optimal dari bentuk maupun motifnya. Strategi solusi adalah dengan inovasi peralatan batik yang mampu mempercepat proses produksi pengcantingan batik secara efisien dan efektif. Untuk itu maka implementasi

a. Inovasi peralatan pencantingan batik kombinasi.

b. Inovasi sarana pendukung yang diperlukan dalam proses produksi batik

Dengan inovasi peralatan dan sarana untuk batik kombinasi, maka motif batik yang akan diproses diharapkan dapat terselesaikan secara efektif dengan kualitas optimal

2) Pendekatan yang dilakukan untuk mengatasi masalah keterbatasan sarana pewarnaan batik. Hal ini teridentifikasi dari mutu pewarnaan batik masih belum maksimalnya. Hal lain berdampak pada pewarnaan dari hasil proses pencatingan memakan waktu lama, tidak efisien. 
Strategi yang dilakukan adalah dengan optimalisasi dan inovasi sarana pewarnaan batik

$$
\begin{array}{ccc} 
& \text { Untuk masalah manajemen maka } & \text { mategi } \\
\text { strategi ditawarkan } & \text { untuk }
\end{array}
$$
menyelesaikan persoalan adalah:

1) Masalah sistem manajemen kususnya manajemen pemasaran konvensional dengan door to door bisa diselesaikan dengan membuat informasi produk yang mudah diakses oleh konsumen. Untuk itu solusi yang ditawarkan adalah dengan membuat informasi produk pemasaran berbasis brosur. Dengan demikian maka konsumen dapat melihat dan mengikuti perkembangan jenis batik malangan serta harganya di brosur, sehingga konsumen akan lebih mudah akses untuk mendapatkan informasi produk.

2) Masalah tatakelola keuangan dan pembukuan. Pendekatan yang perlu dilakukan untuk menyelesaikan masalah ini adalah dengan membuat SOP (standard operating prosedure) tentang langkah langkah dalam proses tatakelola keuangan dan pembukuan. UKM diberi pemahaman dan dilatih cara melakukan pembukuan yang baik.

\section{Rencangan Pelaksanaan Kegiatan}

Rencangan kegiatan yang berupa langkah langkah strategi untuk memberikan solusi atas masalah produksi dan manajemen adalah sebagai berikut:

1) Koordinasi dan diskusi antar anggota tim dengan pengelola UKM. Hal ini dimaksudkan untuk mendapatkan masukan dan gagasan yang digunakan untuk implementasi solusi atas strategi. Penyamaan persepsi dan langkah gerak dalam pelaksanaan program ini menjadi penting dengan cara kerja yang kolegial seluruh anggota tim dan UKM.

2) Merancang inovasi peralatan beserta spesifikasinya, membuat dan sekaligus uji coba, yaitu meliputi :

a. Inovasi peralatan pencantingan batik kombinasi.

b. Inovasi sarana pendukung yang diperlukan dalam proses produksi batik

3) Merancang dan membuat brosur yang memenuhi kriteria perancangan.
4) Pelatihan penggunaan dan pengelolaan pembukuan dan pemasaran kepada UKM.

5) Pembuatan panduan pembukuan.

6) Pelatihan manajemen kendali mutu produk dan pembukuan keuangan.

\section{Partisipasi UKM}

Bentuk partisipasi UKM dalam pelaksanaan program ini adalah sebagai berikut:

1) Turut serta dalam diskusi dan memberikan informasi tentang berbagai persoalan dan menyampaikan kesulitan yang dihadapi.

2) Memberikan masukan sehingga luaran yang dihasilkan benar benar bermanfaat dan sesuai dengan harapan UKM.

3) Ikut menyiapkan sarana dan prasarana dalam uji coba atas inovasi peralatan membatik beserta sarananya yang lain.

4) Mengikuti pelatihan dan tutorial yang diadakan sehingga mengerti tentang aspek produksi dan manajemen.

\section{CAPAIAN}

\section{Profil Batik Malangan}

Batik Malang atau juga biasa disebut Batik Malangan mempunyai tiga ciri utama yaitu, motif dasaran atau latar dari kain batik malang berupa motif batik dari Candi Badut . Motif batik Malang yang diketahui sekarang ini diantaranya adalah motif batik malang sawat kembang pring, kucecwara, celaket, dele kecer, kembang kopi, teratai singo, kembang juwet, kembang jeruk, kembang tanjung, kembang manggar, kembang mayang, dan kembang padma atau saat ini lebih dikenal dengan nama bunga teratai.

Motif batik malang yang menjadi ciri khas tersebut dibuat berdasarkan ilustrasi candicandi hindu peninggalan Kerajaan Kanjuruhan dari abad ketujuh. Salah satu motif batik Malang yang paling populer diantara motif batik bunga teratai. Motif batik Malang yang lain yaitu motif batik Malang Kucecwara. Motif batik tersebut mempunyai komposisi perpaduan motif diantaranya, Mahkota, gambar Tugu Malang, Rumbai Singa, Arca, Bunga Teratai, sulur-sulur juga isen-isen berbentuk belah ketupat. Filosofi dari motif batik Malang tersebut jika ditinjau dari motif yang terbentuk yaitu, gambar tugu Malang perlambang kekuasaan wilayah yang bisa juga merepresentasikan sebagai wujud keperkasaan dan ketegaran. Mahkota yang yang terdapat pada motif batik tersebut merupakan representasi dari bentuk mahkota dari Raja 
Gajayana yang pernah membawa Kerajaan Gajayana menuju puncak kejayaannya. Jika dikaitkan dengan kehidupan masyarakat, sebagai wujud suatu harapan agar yang mengenakan batik Malang ini mampu meraih puncak kejayaan dalam perjalanan hidupnya.

Rumbai Singa mewakili kultur atau budaya masyarakat Malang pada waktu itu yang memiliki jiwa pemberani dengan semangat yang membara dan pantang menyerah seperti "Singo Edan", hingga menjadi lambang Malang saat ini. Bunga Teratai melambangkan suatu keindahan alam yang penuh kesuburan. Menurut kisah cerita hindu era kerajaan singosari, bunga teratai merupakan salah satu jenis bunga Dewa Wishnu sebagai dewa pemelihata alam. Makna yang terkandung dari bunga ini yaitu kearifan atau kebijaksanaan yang mengakibatkan kemakmuran bagi masyarakat yang dipimpinnya..

Motif batik malang modern terbaru dikenalkan oleh para mahasiswa dari Universitas Brawijaya. Batik tersebut dinamakan "Kitab Malangan" yang disarikan dari nama "Kitab" (dibaca dari kanan), merupakan dialek warga Malang yang suka bolak-balik kata. Motif "Kitab Malangan" berupa kaligrafi yang membentuk pola sebuah singo edan. Seiring dengan perkembangan jaman dan disadarinya bahwa batik Malang merupakan warisan seni budaya Nusantara maka pemerintah setempat kembali menggiatkan para perajin batik untuk kembali pada patron awalnya yaitu dikerjakan kembali dengan tangan seperti dalam proses pembuatan batik tulis. Perlu diketahui juga bahwa beberapa motif batik malang memiliki hak paten atas motif batik Malang yang tercipta sehingga tidak sembarangan orang boleh memperbanyak.

Batik Malang sampai sekarang belum begitu populer di kalangan masyarakat Indonesia secara keseluruhan. Pemerintah selalu mengupayakan penggalian motif batik Malang terbaru bersama organisasi terkait lainnya dengan mengadakan pagelaran busana maupun

Beberapa contoh produk batik yang telah dihasilkan seperti terdapat pada, Gambar 4, dan Gambar 5. Pada gambar produk tersebut menunjukkan bahwa diperlukan inovasi peralatan yang mampu meningkatkan produktifitas dan kualitas batik. pagelaran budaya untuk mengunggah khasanah budaya serta untuk lebih mempopulerkan batik Malangan.

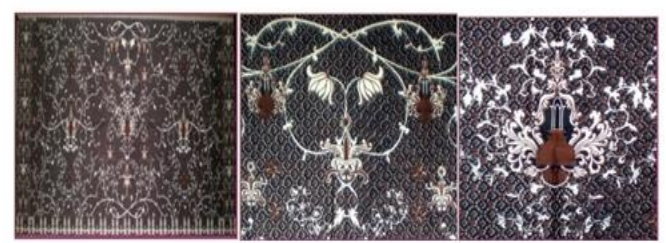

Gambar 1 : Motif Batik Malangan

\section{Aspek Produksi}

Dari Tabel 1 di bawah ini dapat dijelaskan bahwa kondisi UKM masih keterbatasan dimilikinya peralatan batik. Sementara dengan peralatan batik yang lengkap, akan mampu meningkatkan kinerja produksi batik Malangan. Seperti yang tampak dalam Gambar 2 dan Gambar 3, pekerja masih menggunakan peralatan manual yang hasilnya batik masih kurang rapi dan waktu yang digunakan dalam proses batik sangat lama. Sedangkan pada Gambar 4 menunjukkan aktifitas UKM yang sudah memproduksi batik konvesional dengan keterbatasan peralatan batik

Tabel 1. Kondisi UKM pada Aspek Produksi

\begin{tabular}{|r|l|l|l|}
\hline No. & \multicolumn{1}{|c|}{ Uraian } & \multicolumn{1}{|c|}{$\begin{array}{c}\text { UKM "Batik Asli } \\
\text { Malangan" }\end{array}$} & \multicolumn{1}{|c|}{$\begin{array}{c}\text { UKM "Batik Warna } \\
\text { Malangan" }\end{array}$} \\
\hline 1 & Nama bahan baku & Kain batik mori, dll & Kain batik mori, dll \\
\hline 2 & Asal & $\begin{array}{l}\text { Malang kelurahan Merjasari } \\
\text { Lowokwaru }\end{array}$ & $\begin{array}{l}\text { Malang kelurahan Merjasari } \\
\text { Lowokwaru }\end{array}$ \\
\hline 3 & Lama Usaha & 10 Tahun & 5 Tahun \\
\hline 4 & Peralatan Produksi & Sudah ada manual & Sudah ada manual \\
\hline 5 & Jenis Peralatan & Semua alat masih manual & Semua alat masih manual \\
\hline 6 & Bahan Pewama & Ada, Sintetis & Ada, Sintetis \\
\hline 7 & Dingklik bangku & Ada terbatas & Ada terbatas \\
\hline 8 & Bandul & Ada manual & Ada teratas \\
\hline 9 & Taplak & Ada & Ada \\
\hline 10 & Cangting & Ada manual & Ada manual \\
\hline 11 & Meja kayu & Sudah ada manual & Sudah ada manual \\
\hline 12 & Lilinmalam & Ada & Ada \\
\hline 13 & Wajan dan Kompor & Ada terbatas & Ada terbatas \\
\hline 14 & Gawangan & Ada terbatas & Ada terbatas \\
\hline 15 & Metode Pengejaan & Sudah terampil manual & Belum terampil manual \\
\hline 16 & Tenaga kejja & 2 orang & 1 orang \\
\hline 17 & Kapasitas produksi & $\begin{array}{l}50 \text { s/d } 60 \text { Batik malangan } \\
\text { Dalam } 1 \text { bulan }\end{array}$ & $\begin{array}{l}20 \text { s/d } 30 \text { batik malangan } \\
\text { Dalam } 1 \text { bulan }\end{array}$ \\
\hline & & Catatan: * Data disusun berdasarkan hasil survey yang dilakukan oleh Yatimah (2015)
\end{tabular}

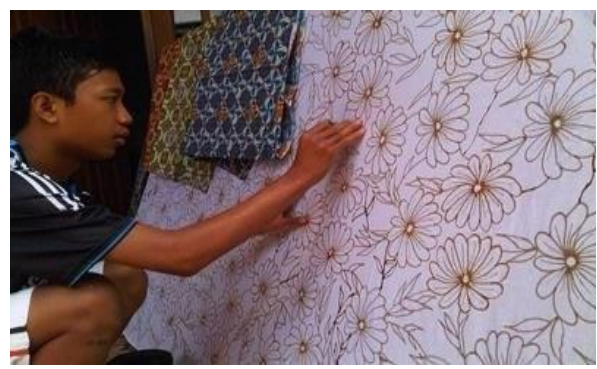

Gambar 2. Proses Produksi Batik 


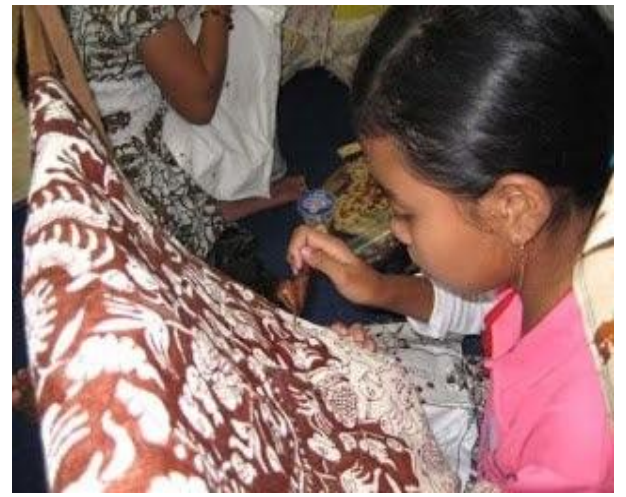

Gambar 3. Proses Produksi Batik

Malangan

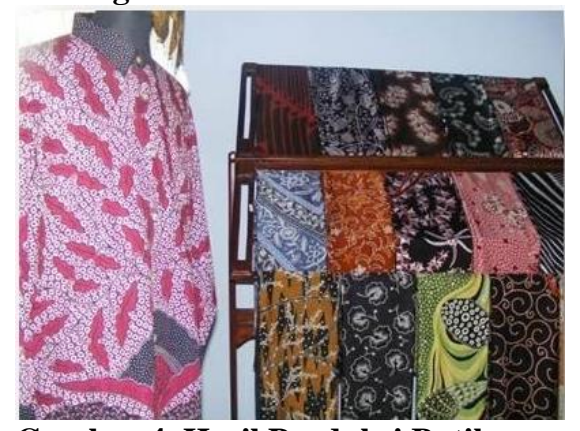

Gambar 4. Hasil Produksi Batik

Malangan

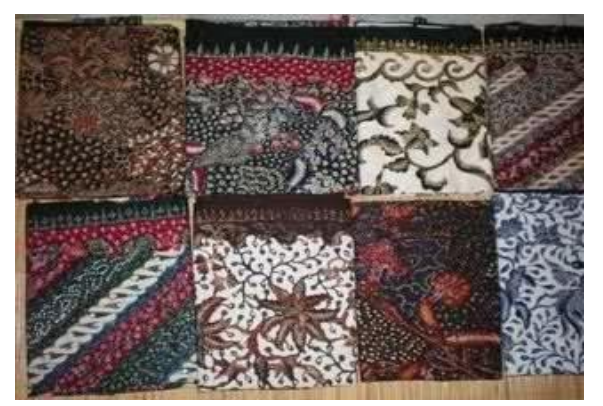

Gambar 5. Hasil Akhir Produksi Batik Malangan

\section{Proses Produksi}

Berdasarkan pengalaman UKM Pengrajin batik Malangan rata-rata dapat memproses 20-50 buah batik. Jumlah bahan baku batik yang diproses setiap hari sangat bervariasi dan tidak bisa diprediksi secara pasti karena proses pembuatan batik Malangan tergantung pada pesanan. Tenaga kerja yang terlibat selama proses produksi adalah 2 orang pada masing masing UKM Pengrajin Batik. Proses produksi pada masing-masing UKM Pengrajin memiliki kesamaan. Alur produksi batik Malangan pada pada UKM Batik di Kelurahan Merjosari Malang sebagai berikut:
1. Kain mori/batik dipersiapkan untuk diproses.

Kain batik/mori Kain Mori adalah kain tenun benang kapas hasil olahan pabrik dengan anyaman polos dan diputihkan. Kain mori mempunyai ketebalan, kehalusan dan kerapatan kain yang pas, sehingga seringkali dibuat untuk membatik sama seperti kain- kain pada umumnya, kain mori memiliki beberapa tingkatan kualitas, tergantung kualitas benang tenun dan kerapatan anyaman.

2. Penyorekan

Nyorek atau memola adalah proses menjiplak atau membuat pola di atas kain mori dengan cara meniru pola motif yang sudah ada, atau biasa disebut dengan ngeblat. Pola biasanya dibuat di atas kertas roti terlebih dahulu, baru dijiplak sesuai pola di atas kain mori. Tahapan ini dapat dilakukan secara langsung di atas kain atau menjiplaknya dengan menggunakan pensil atau canting. Namun agar proses pewarnaan bisa berhasil dengan baik, tidak pecah, dan sempurna, maka proses batikannya perlu diulang pada sisi kain dibaliknya. Proses ini disebut ganggang.

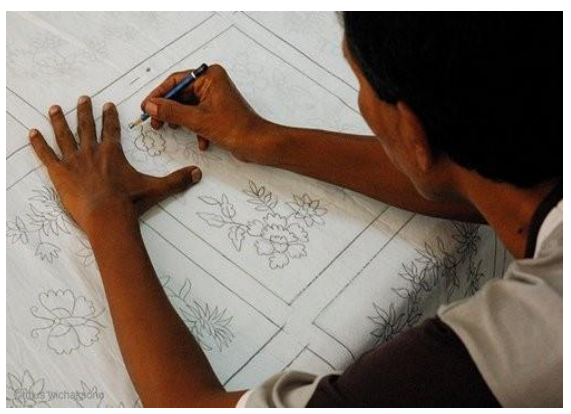

\section{Gambar 6 Proses Penyorekan}

\section{Pencantingan}

Pertama, gambar pola motif batik yang telah ditentukan dengan pensil. Sebenernya langsung nyanting dengan malam sih tidak apa apa kak, tapi berhubung aku masih pemula jadi harus pake pensil biar waktu dicantingnya nanti rapi. setelah sudah digambar semua motifnya, hidupkan kompornya dengan api kecil saja lalu panaskan malam di atas wajan sampai malam cair. Tapi jangan terlalu cair sekali ya kak, bisa-bisa nanti hasilnya 
saat dicanting bisa meleber ke manamana. Usahakan saat dicanting, malamnya tembus ke bagian belakang kainnya. Menyanting ini adalah bagian yang tersulit, dan hati-hati sama proses pencantingan ini soalnya malam yang panas ini bisa melukai kita.

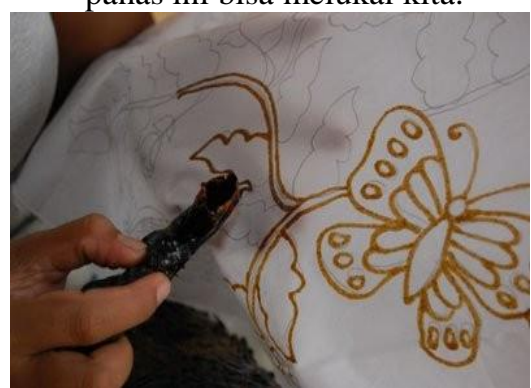

\section{Gambar.7 Proses}

Pencantingan/Pembatikan

\section{Nembok}

Yaitu proses menutupi dengan lilin malam bagian-bagian yang akan tetap berwarna putih (tidak berwarna). Canting untuk bagian halus, atau kuas untuk bagian berukuran besar. Tujuannya adalah supaya saat pencelupan bahan kedalam larutan pewarna, bagian yang diberi lapisan lilin tidak terkena.

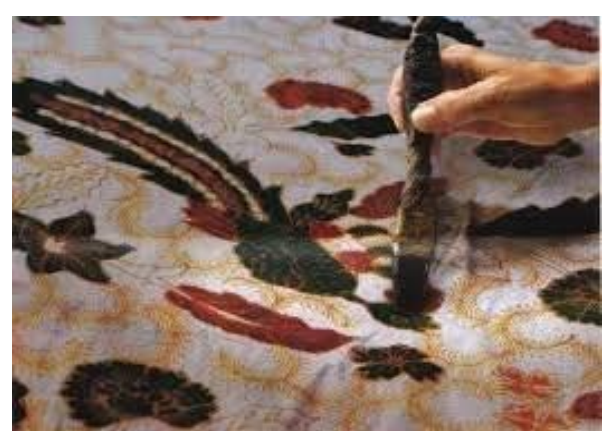

\section{Gambar. 8 Proses Penembokan}

\section{Perendaman dan Pewarnaan}

Proses pencelupan kain yang sudah dibatik ke cairan warna secara berulang-ulang sehingga mendapatkan warna yang diinginkan.Dalam proses pemberian warna terdapat istilah nyoga yaitu proses pencelupan/pewarnaan untuk mendapatkan warna coklat.Sama dengan proses nembok, semakin banyak warna yang akan dibuat proses medel-pun juga akan semakin seringProses pencelupan kain yang sudah dibatik ke cairan warna secara berulang -ulang sehingga mendapatkan warna yang diinginkan.Dalam proses pemberian warna terdapat istilah nyoga yaitu proses pencelupan/pewarnaan untuk mendapatkan warna coklat.Sama dengan proses nembok, semakin banyak warna yang akan dibuat proses medel-pun juga akan semakin sering.

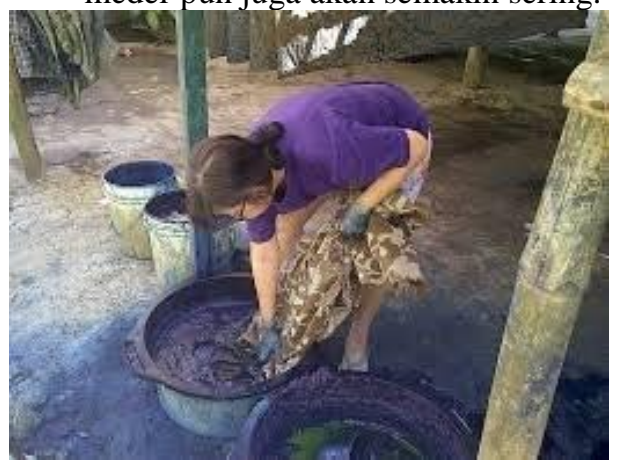

Gambar. 9 Proses Pewarnaan

6. Pengerokan

Adalah proses menghilangkan lilin/malam menggunakan alat penggerok yang biasanya terbuat dari lempengan logam.Setelah dilakukan pengerokan,beberapa motif dilanjutkan dengan proses mbironi, yaitu menutup bagian-bagian tertentu dengan malam agar tidak terkena warna pada proses pewarnaan berikutnya. Proses nembok,medel dan ngerok adalah satu kesatuan dalam pembentukan warna yang diinginkan oleh si pembatik. Semakin banyak warnanya akan semakin sering 3 proses tersebut berulang.

7. Proses pelorotan

Proses selanjutnya adalah nglorot, dimana kain yang telah berubah warna direbus air panas. Tujuannya adalah untuk menghilangkan lapisan lilin, sehingga motif yang telah digambar sebelumnya terlihat jelas. Anda tidak perlu kuatir, pencelupan ini tidak akan membuat motif yang telah Anda gambar terkena warna, karena bagian atas kain tersebut masih diselimuti lapisan tipis (lilin tidak sepenuhnya luntur). Setelah selesai, maka batik tersebut telah siap untuk digunakan. 


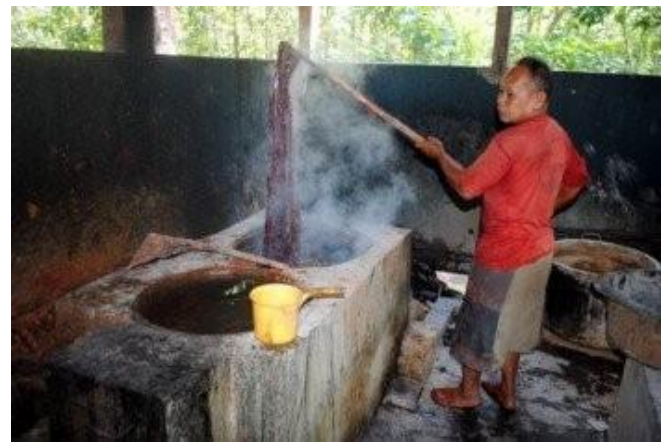

Gambar. 10 Proses Pelorotaan

\section{Aspek Manajemen}

Sedangkan aspek manajemen, kondisi UKM secara garis besar juga masih sangat sederhana dan konvensional sehingga kemampuan untuk mengembanggkan usaha yang lebih besar masih sulit untuk dicapai. Secara rinci, kondisi UKM adalah sebagaimana terdapat pada Tabel 2.

Tabel 2 Kondisi UKM pada Aspek Manajemen

\begin{tabular}{|r|l|l|l|}
\hline No. & \multicolumn{1}{|c|}{ Aspek kondisi } & UKI “Batik Asli Nalangan” & UKMI “Batik Warna Malangan” \\
\hline 1 & Lama Usaha & 10 Tahun & 5Tahun \\
\hline 2 & Stok Bahan baku & Stok yang dimiliki terbatas & $\begin{array}{l}\text { Stok yang dimiliki sangat } \\
\text { terbatas }\end{array}$ \\
\hline 3 & Cara Pembuatan & Dibuat berdasarkan pesanan & Dibuatberdasarkan pesanan \\
\hline 4 & Pengemasan & Belum ada & Belum ada \\
\hline 5 & $\begin{array}{l}\text { Keberadaan user } \\
\text { manual }\end{array}$ & Belum ada user manual & Belum ada user manual \\
\hline 6 & $\begin{array}{l}\text { Cara pemasarn dan } \\
\text { promosi }\end{array}$ & $\begin{array}{l}\text { Konvensional dan mood to } \\
\text { mood }\end{array}$ & $\begin{array}{l}\text { Konvensional dan mood to } \\
\text { mood }\end{array}$ \\
\hline 7 & Kendalimutu & $\begin{array}{l}\text { Masih belum dil lakukan } \\
\text { dengan baik }\end{array}$ & Masih belum di lakukan \\
\hline 8 & Permodalan & Sudah ada tapi sangat terbatas & Tidak punya modal yang cukup \\
\hline 9 & $\begin{array}{l}\text { Pembukuan } \\
\text { keuangan }\end{array}$ & Belum dilakukan secara baik & Belum dilakukan \\
\hline
\end{tabular}

Kondisi aspek manajemen yang dilakukan UKM secara operasional di lapangan adalah sebagai berikut:

1) Sistem pemasaran yang dilakukan masih dengan cara konvensional dari mulut ke mulut menawarkan ke penduduk desa maupun kota secara langsung. Setelah mendapatkan pesanan baru dibuatkan sesuai dengan banyaknya pesanan atau datang lang ke tempat produksi, Waktu yang dibutuhkan untuk menawarkan batik malangan lebih banyak dan tidak efektif.

2) Tidak ada sistem stok batik malangan yang banyak, sehingga ketika ada pemesanan yang bersamaan maka dengan jumlah yang banyak maka sering terjadi keterlambatan produksi sehingga penyerahan batik pesanan menjadi sering terlambat.

3) Masalah kendali mutu produk masih belum ada dengan baik sehingga beberapa produk ketika diserahkan pada konsumen masih ada motif batik yang pecah dan dikomplain oleh konsumen. Produk batik malangan juga yang membutuhkan pencantingan yang baik akan digunakan pencantingan cap yang kuat sehingga dapat menghasilkan batik malangan yang tidak mudah pecah dan bagus.

4) Tidak ada pembukuan yang tertib dan disiplin dari hasil penjualan tersebut sehingga tidak bisa diketahui dengan jelas seberapa besar untungnya. Kondisi hal tersebut juga tidak bisa terlepas dari adanya tidak terpisahnya antara keuangan usaha dengan kebutuhan keluarga.

Dari tabel 2 di atas terlihat bahwa secara manajemen masih banyak hal yang belum dilakukan, baik itu yang menyangkut manajemen bahan baku, manajemen pemasaran, maupun manajemen keuangan. Pemasaran masih menggunakan cara konvensional menawarkan dari mulut ke mulut, sehingga tidak efektif. Sedangkan dari aspek keuangan, masih belum dilakukan tatakelola pembukuan yang akurat. Hal ini tidak terlepas dari kondisi finansial keluarga yang masih keterbatasan, keterbatasan membukukan antara keuangan dari hasil usaha dengan kebutuhan keluarga sehari hari.

\section{Potensi dan Peluang Bisnis}

Potensi dan peluang bisnis pengrajin batik malangan ini sangat prospektif. Setiap tahun banyak konsumen dari dalam maupun dari luar Kota Malang, terutama sekolah-sekolah dan perkatoran yang sudah menerapkan pemakaian batik, selalu mencari batik malangan sampai ke tempat-tepat produksi batik di Malang. Hal ini karena terkait dengan motif batik malangan yang selalu menyuguhkan motifmotif batik malangan yang disukai oleh konsumen. Sementara itu, kebutuhan akan batik malangan ini masih belum bisa dipenuhi semua terutama jenis dan motif- 
motif batik yang baru yang mampu memberikan sentuhan inovasi dan kreatif sehingga menarik konsumen.

Fakta menunjukkan bahwa saat ini pesanan batik malangan terus berkembang dengan membutuhkan banyak batik. Jumlah sekolah-sekolah yang menbutuhkan batik untuk siswanya sangat banyak dan terus berkembang terutama di perkotaan. Hampir disetiap daerah di wilayah Malang terdapat sekolah-sekolah dan perkatoran yang memerlukan batik. Dari sini maka potensi untuk pemasaran batik malangan menjadi sangat potensial dan bisa dikembangan sebagai usaha yang mempunyai peluang yang cukup bagus.

\section{Implementasi Strategi dan Solusi}

Pengembangan dan peningkatan produksi batik Malangan diperlukan adanya strategi solusi sebagai langkah optimaslisasi kompetisi antar produk batik. Strategi solusi produk produk batik Malangan konvensional pada UKM Kelurahan Merjosari Malang agar dapat bersaing maksimal, maka dilakukan melalui diversifikasi produk batik kombinasi. Hasil yang sudah dicapai dalam rangka strategi solusi atas permasalahan, berupa inovasi peralatan pencantingan batik kombinasi dan inovasi sarana pendukung yang diperlukan dalam proses produksi batik. Strategi solusi inovasi peralatan batik akan mampu mempercepat proses produksi pengcantingan batik secara efisien dan efektif.

Untuk masalah manajemen, strategi yang dilakukan antara lain dengan membuat informasi produk yang mudah diakses oleh konsumen. Langkah lebih lanjut atas solusi, dengan membuat informasi produk pemasaran berbasis brosur. Manajemen pada konteks masalah tatakelola keuangan dan pembukuan, diimplementasikan dengan membuat SOP (standard operating prosedure) terkait langkah langkah dalam proses tatakelola keuangan dan pembukuan. Lebih lanjut UKM diberi pemahaman dan dilatih cara melakukan pembukuan yang baik.

\section{Implementasi inovasi peralatan pencantingan batik kombinasi dan implementasi inovasi sarana pendukung proses produksi batik}

Dalam hal cetakan batik cap, hal ini terbuat dari lempengan tembaga yang bisa bertahan tiga sampai dengan lima tahun (3 s.d 5 tahun). Ukuran cetakan adalah $20 \mathrm{~cm} \mathrm{x}$ $20 \mathrm{~cm}$ dan dibuat dari bahan tembaga, sesuai dengan namanya cara membuatnya di Cap.

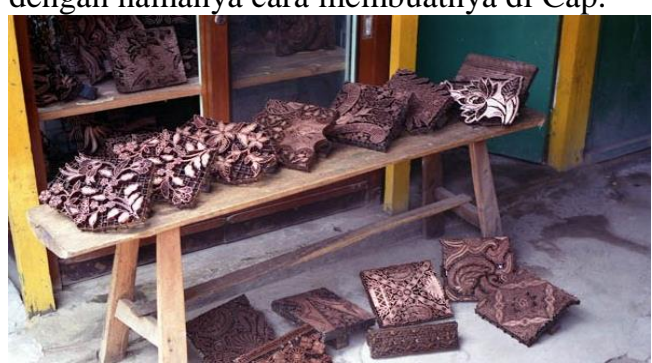

Gambar 11 Cetakan Batik Cap

Cetakan itu sendiri merupakan design motif yang akan dicap pada kain batik, hasil yang didapat dengan metode ini hampir mirip dengan batik tulis. Hasilnya tembus akan tetapi masih dibawah kualitas batik tulis tembusnya. Untuk kontras warna tidak diragukan lagi, hasil warna untuk batik cap sendiri sangat terang, tidak mudah luntur.

Proses pembuatan cetakan batik cap ini memerlukan waktu sekitar satu mingguan, proses penjemuran dan proses pengecapan sangat berpengaruh terhadap hasil akhir sebuah Batik Cap. Kesannya memang mudah, akan tetapi sangat sulit sekali untuk diimplementasikan.

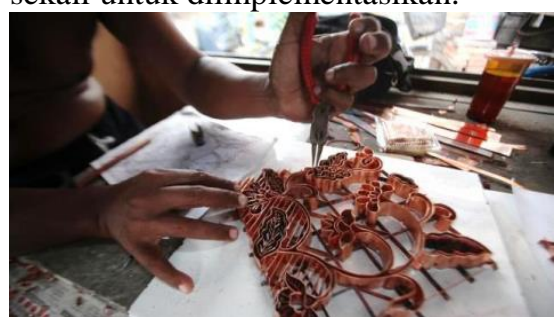

\section{Gambar 12 Proses Pembuatan Cetakan Batik Cap}

Kemudian, disamping cetakan batik cap sebagai alat batik cap, maka diperlukan sarana untuk mengecap batik tersebut, yaitu meja cap. Meja cap yang digunakan dalam membuat batik cap terbuat dari kayu, dengan rangkaian alat meja batik cap memiliki spesifikasi sebagai berikut: papan kayu 200 $\mathrm{cm} \times 100 \mathrm{~cm} \quad, \quad$ spon/busa, kayu 45, triplek, plastik bening, kayu meja, plastik perlak, kaki meja

Tinggi meja dibuat sedemikian rupa sehingga orang yang mencap dapat bekerja 
dengan baik dan nyaman. Permukaan meja cap dilapisi dengan kasur/busa, kain blacu dan kain serak tipis. Kasur terbuat dari spon/busa, setebal kurang lebih $10 \mathrm{~cm}$ dan dibuat rata agar hasil pengecapan bagus. Kain blacu berukuran lebih besar sedikit dari meja atau kasur, yang digunakan untuk menutup bagian atas kasur. Kegunaannya untuk menjaga agar pada waktu pengecapan malam yang mungkin menembus kain, tidak langsung kena kasur. Kain serak tipis ukurannya sama dengan kain blacu. Kain ini yang terletak di bagian dalam dan selalu dalam keadaan lembab (diseka dengan larutan soda abu).

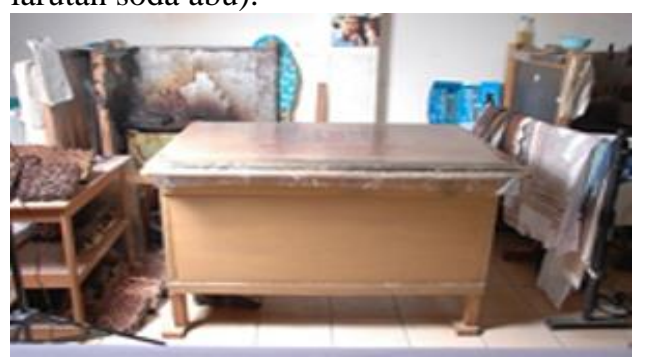

\section{Gambar.13 Meja Batik Cap}

Selanjutnya alat yang digunakan dalam proses pembuatan batik cap adalah bak pewarna. Penggunaan bak pewarna yaitu, kalau sudah selesai di cap, kain tersebut dirapikan, ditumpuk dan dilipat dan memasuki ruang tunggu pewarnaan. Ini tempat pewarnaan, ada beberapa bak yang di dalamnya berisi air berwana dan berbedabeda tiap bak-nya.

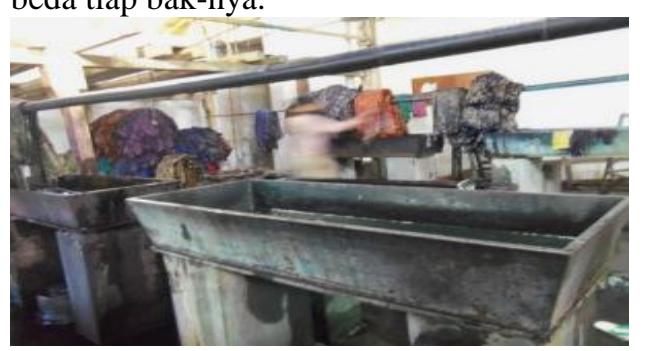

Gambar 14 Bak Pewarna

Adapun proses pencapuran bahan pewarna pada masing-masing bak pewarna adalah sebagai berikut:

1) Bak pertama terdiri atas: Naptol 10 gram, TRO 5 gram, dan air panas 1,5. Costic Soda 5gram dicampur ke dalam air 1,5 lt, dengan memasukan costic soda dan TRO ke dalam air hangat hingga larut, kemudian naptol dicampurkan kedalamnya sampai larut.
2) Bak kedua terdiri atas: air dingin 1,5 lt, garam 20 gram. Masukkan garam ke dalam air dingin dan diaduk sampai rata.

3) Bak ketiga terdiri atas: air dingin \pm 2 liter dan larutan Fixanol $\pm 10 \mathrm{ml}$. masukkan Fixanol ke dalam air dan aduk samapai rata. Bak ketiga berfungsi sebagai penguat atau pengunci warna.

4) Bak keempat terdiri atas air \pm 5 liter, berfungsi sebagai pembilas.

Sedangkan proses pewarnaan pada kain adalah sebagai berikut:

1) Sebelum memasuki tahap pencelupan, kain harus diberi motif dengan teknik ikat atau jumput. Teknik ikat/jumput disesuaikan dengan kreativitas masingmasing. Jadi, motif pada kain disesuaikan dengan keinginan pembatik.

2) Setelah proses pemberian motif selesai, masukkan kain ke dalam bak pertama. Lalu tiriskan.

3) Kemudian, masukkan ke dalam bak kedua yang berisi zat warna, tiriskan.

4) Pada tahap selanjutnya, masukkan ke dalam bak ketiga yang berisi larutan fixanol sebagai pengikat warna agar warna tidak cepat memudar, lalu tiriskan.

5) Tahap terakhir, masukkan kain pada bak keempat untuk dibilas. Jemur kain dengan tidak terkena matahari secara langsung (cukup terkena angin).

6) Ikatan pada kain dapat dilepas agar dapat mengetahui hasil motif yang sudah dibuat.

Pada tataran baku sarana batik, adalah canting. Canting untuk membatik adalah alat kecil yang terdiri dari gagang/tangkai terbuat dari bambu, nyamplungan/badan canting (tempat cairan lilin) dan carat/cucuk (tempat keluarnya lilin waktu membatik) yang terbuat dari tembaga. Canting ini dipakai untuk menuliskan pola Batik dengan cairan lilin (malam). Menurut fungsinya ada canting reng-rengan (untuk membatik reng-rengan batikan pertama sesuai pola atau tanpa pola) dan canting isen (untuk membatik isi bidang). Menurut besar kecil cucuk ada cucuk kecil, sedang dan besar. Menurut banyaknya cucuk ada canting cecekan/cucuk satu, canting 
loron/cucuk dua, canting telon/cucuk tiga, canting prapatan/cucuk empat, canting liman/cucuk lima, canting byok/cucuk tujuh atau lebih dan canting renteng/galaran (bercucuk genap tersusun dari atas ke bawah).

Seiring perkembangan jaman kini tengah dikembangkan inovasi baru berupa canting elektronik. Canting elektronik ini terdiri dari tiga bagian utama, yakni bak penampung lilin batik atau malam, tangkai pemegang, dan alat kontrol suhu yang berfungsi mengontrol suhu canting. Salah satu kelebihan lain, paruh canting bisa dicopot dan diganti sesuai ukuran yang diinginkan. Seluruh jenis paruh canting, yakni ceceg, klowong, tembogan, dobel ceceg, dan dobel klowong bisa dipasang di tubuh canting. Padahal pada canting tradisional, lima jenis ini terpisah-pisah.

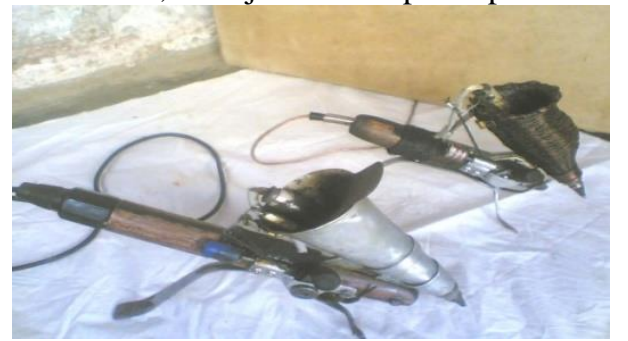

\section{Gambar 15 Canting Elektrik}

Dengan canting elektrik ini membuat batik tulis menjadi sangat mudah, tanpa harus telaten, tanpa harus hati hati, penggunaanya sangat mudah layaknya seperti kita menulis menggunakan spidol ato pulpen saja. Canting ini di lengkapi dengan tuas pengatur keluar nya malam/cat dan mata canting nya dapat di ganti ganti sesua kebutuhan saat bekerja (dapat dilakukan saat sdang dipakai, malam/cat tidak akan tumpah karena ada klep/katup penahan Malam/cat).

Kain batik yang indah dan menarik tentun tidak terlepas dari bagaimana kelihaian tangan-tangan pengrajin dalam mengolahnya. Berbagai macam cara dapat dilakukan untuk menciptakan karya seni tradisional ini dan tentunya dengan keuletan dalam menggunakan teknik-teknik tradisional alami yang mampu menghasilkan kain batik dengan ceceg-ceceg yang membentuk suatu pola motif indah akan membuat nilai dari batik tersebut menjadi tinggi dibandingkan dengan pembuatan batik menggunakan teknik moderen seperti cap, printing, sablon dan sebagainya. Dalam pembuatannya batik tradisional ada beberapa perlengkapan yang harus dipersiapkan, diantaranya adalah gawangan.

Gawangan adalah alat bantu membatik yang berbentuk gawang dengan dua kaki di kanan dan kiri yang berfungsi sebagai peyanggaa sebuah pilar atau bilah. Tinggi gawangan $50 \mathrm{~cm}$ dan panjang bilah 1m. Gawangan ini terbuat dari bahan kayu. Fungsi utama gawangan yaitu sebagai tempat untuk menaruh kain yang akan diberi pola batik.

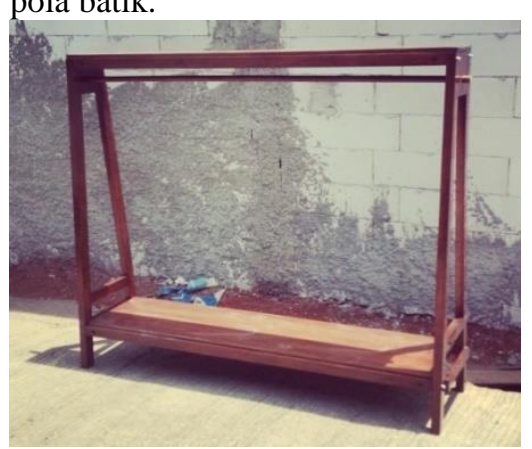

Gambar 16. Gawangan

Agar budaya batik tetap lestari dan semakin menarik, diperlukan inovasi, baik dalam desain maupun teknologi proses pembuatannya. Salah satu alat terpenting dalam proses pembuatan batik adalah kompor. Sebelumnya masyarakat membatik menggunakan kompor minyak tanah, sehingga kestabilan panas kurang terjaga. Kompor elektrik hadir untuk memecahkan masalah itu. Setelah bagian kain tertutup "malam" dengan sempurna, maka proses melukiskan motif batik sesuai selera dengan "canting" di kain semakin mudah. Agar proses mencairkan "malam" berjalan stabil, maka membutuhkan kompor dengan suhu panas yang stabil pula.

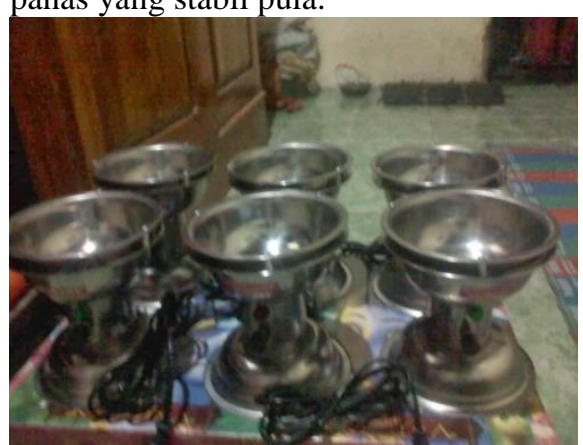

Gambar 17. Kompor Elektrik

Transformasi dan inovasi teknologi khususnya di bidang perbatikan pada era 
saat ini sangat dibutuhkan oleh para UKM perajin batik Malangan pada umumnya dan para UKM perajin batik Malangan di Kelurahan Merjosari Malang kususnya. Pentingnya optimalisasi produk dan kualitas batik pada UKM perajin batik Malangan di Kelurahan Merjosari Malang agar bisa bersaing di pasar, tercetuslah ide bagaimana strategi upaya meningkatkan kualitas dan kuantitas produksi secara efisien. Strategi bersaing tersebut antara lain dengan mentransformasi teknologi dan inovasi peralatan batik Malangan konvensional melalui diversifikasi produk batik kombinasi.

\section{Strategi Aspek Manajemen UKM Batik Malangan di Kelurahan Merjosari Malang}

Empat fungsi manajemen yang sering disebut "POAC", yaitu Planning, Organizing, Actuating, dan Controlling, menjadi strategi solusi atas permasalahan pada aspek manajemen. Dua fungsi yang pertama dikategorikan sebagai kegiatan mental sedangkan dua berikutnya dikategorikan sebagai kegiatan fisik. Sementara suatu manajemen bisa dikatakan berhasil jika keempat fungsi di atas bisa dijalankan dengan baik. Demikian pada UKM batik Malangan di Kelurahan Merjosari Malang. Kelemahan pada salah satu fungsi manajemen akan mempengaruhi manajemen UKM. Dampaknya adalah tercapainya kualitas dan kuantitas produk batik tidak sesuai harapan. Empat fungsi manajemen tersebut menjadi solusi strategi implementasikan pada kondisi UKM batik Malangan di Kelurahan Merjosari Malang.

\section{Fungsi Perencanaan (Planning).}

Implementasi dalam proses, upaya yang dilakukan adalah untuk mengantisipasi kecenderungan di masa yang akan datang dan penentuan strategi serta taktik yang tepat untuk mewujudkan target dan tujuan UKM Batik Malangan di Kelurahan Merjosari Malang. Kegiatan dalam fungsi perencanaan antara lain : menetapkan pasar sasaran, merumuskan strategi untuk mencapai pasar sasaran, menentukan sumber-sumber daya yang diperlukan, menetapkan standar / indikator keberhasilan dalam pencapaian tujuan dan pasar yang dituju

Strategi dan taktik dalam fungsi perencanaan tersebut diimplementasikan dengan menggunakan metode analisis SWOT (Strength, Weakness, Opportunity and Threat). Implementasikannya dengan perencanaan strategis yang digunakan untuk mengevaluasi kekuatan, kelemahan, peluang, dan ancaman UKM Batik Malangan di Kelurahan Merjosari Malang. Proses ini melibatkan penentuan tujuan yang spesifik, mengidentifikasi faktor internal dan eksternal yang mendukung, maupun yag tidak mendukung, dalam mencapai tujuan UKM Batik Malangan di Kelurahan Merjosari Malang.

\section{Fungsi Pengorganisasian (Organizing)}

Implementasikan strategi dan taktik dalam sebuah struktur UKM yang tepat dan tangguh, sistem dan lingkungan yang kondusif, dan dapat memastikan bahwa semua pihak dalam UKM dapat bekerja secara efektif dan efisien guna pencapaian tujuan organisasi. Kegiatan dalam fungsi pengorganisasian antara lain : mengalokasikan sumber daya / sarana, merumuskan dan menetapkan tugas, menetapkan prosedur yang diperlukan, struktur organisasi yang menunjukkan adanya garis kewenangan dan tanggungjawab, sehingga setiap pekerja akan bergerak dan bertindak sesuai dengan job description \& kewenangannya, memiliki tanggung jawab atas pekerjaan yang telah dilaksanakan, kegiatan pelatihan dan pengembangan tenaga kerja. Tersebut di atas, sangatlah penting agar dapat menyegarkan dan menambah wawasan pekerja, kegiatan penempatan sumber daya manusia pada posisi yang paling tepat atau dengan kata lain strategi yang telah ditetapkan harus dilaksanakan oleh pekerja yang dinilai mampu dan layak dan memiliki pengetahuan yang cukup di bidang batik.

\section{Fungsi Pengarahan Dan Implementasi (Actuating)}

Implementasi program agar dapat dijalankan oleh seluruh pihak dalam UKM serta proses memotivasi agar semua pihak dapat menjalankan tanggungjawabnya dengan penuh kesadaran sehingga 
produktifitas tinggi. Kegiatan dalam fungsi pengarahan antara lain : mengimplementasikan proses kepemimpinan, pembimbingan, pemberian motivasi kepada tenaga kerja agar dapat bekerja secara efektif dan efisien dalam pencapaian tujuan, memberikan tugas dan penjelasan rutin mengenai pekerjaan dan menjelaskan kebijakan yang ditetapkan.

\section{Fungsi Pengawasan Dan Pengendalian (Controlling ) \\ Implementasi untuk memastikan} seluruh rangkaian kegiatan yang telah direncanakan, diorganisasikan dapat berjalan sesuai dengan target yang diharapkan sekalipun berbagai perubahan terjadi. Kegiatan dalam fungsi pengawasan dan pengendalian antara lain : mengevaluasi keberhasilan dalam pencapaian tujuan dan target bisnis sesuai dengan indikator yang telah ditetapkan. Hal ini harus secara rutin dilakukan supaya terlihat pada point mana target yang telah tercapai dan target yang belum tercapai sehingga dapat diambil langkah penyelesaian.

\section{KESIMPULAN DAN SARAN Kesimpulan}

1. Motif batik Malangan mengharapkan adanya suatu keluhuran dari pemakainya untuk selalu berdiri tegak, berani, bertanggung jawab dengan penuh rasa hormat agar mampu menyatu dengan lingkungan.

2. Potensi dan peluang bisnis pengrajin pada UKM batik Malangan sangat prospektif. Setiap tahun banyak konsumen dari dalam maupun dari luar Kota Malang, terutama sekolahsekolah dan perkatoran yang sudah menerapkan pemakaian batik, selalu mencari batik Malangan sampai ke tempat-tepat produksi batik di Malang.

3. Perlu transformasi inovasi teknologi khususnya di bidang perbatikan baik produk maupun manajemen pengelolaannya, karena sangat dibutuhkan oleh para UKM batik Malangan.

4. Strategi diversifikasi produk dan inovasi peralatan produksi batik sebagai upaya peningkatan jumlah produksi. Strategi efisiensi dengan cara mentransformasi teknologi.

5. Inovasi peralatan dan inovasi sarana membatik menjadi salah satu upaya untuk meningkatkankualitas dan kuantitas produk batiki secara efisien dan efektif.

\section{Saran}

Kelompok UKM "Batik Asli Malangan" dan "Batik Warna Malangan" agar benar-benar dapat konsisten dalam meningkatkan produksinya dengan kualitas dan kuantitas yang optimal. Eksistensi inovasi dan deversifikasi produk upaya maksimalisasi produk batik tetap diimplementasikan, mengingat batik sangatlah penting bagi Indonesia karena batik merupakan ciri khas bangsa Indonesia dan merupakan budaya, identitas yang tidak bisa dilepaskan dari bangsa Indonesia. Sementara bahwa batik telah diklaim oleh negara lain, maka kita dianjurkan bahkan diwajibkan menjaga kebudayaan batik yang kita miliki.

\section{DAFTAR PUSTAKA}

1. Direktorat Penelitian dan Pengabdian kepada Masyarakat, DIKTI. 2013. Panduan Pelaksanaan Penelitian Dan Pengabdian Kepada Masyarakat Di Perguruan Tinggi Edisi IX.

2. Hasanudin. 1974. Batik Pesisiran, skripsi desain, FSRD ITB.

3. Hasanudin. 1997. Pengaruh Etos Dagang Santri pada Batik Pesisiran, tesis desain, FSRD ITB.

4. http: // www.bi.go.id/sipuk/lm/ind/batik/pema $\underline{\text { saran }}$

5. Aliya, 2010. Batik Pekalongan.Jakarta Timur : CV. Rama Edukasitama

6. Hindayani, Fisika, 2009. Mengenal dan Membuat Batik. Jakarta Selatan : Buana Cipta Pustaka

7. Ismadi. 2011. Seni Kerajinan/Kriya Batik, Pendidikan Seni Kerajinan Jur. Pend. Seni Rupa FBS UNY.

8. Nasron, D. Yussac. 1969. Seni Batik, skripsi desain, FSRD ITB 
9. Mistaram. 2009. Revitalisasi dan Eksistensi Batik Malangan. Malang: Jurusan

Seni dan Desain

10. Moleong, Lexy J. 2002 Metodologi Penelitian Kualitatif. Bandung: PT. Remaja Rosdakakarya

11. Sachari, Agus.2004.Metodologi Penelitian Budaya Rupa. Jakarta: Penerbit Erlangga.

12. Yusak, Anshari dan Kusrianto. 2011. Keeksotisan Batik Jawa Timur. Jakarta: PT

Elek Media Komputindo. 